\title{
Improving Gender Balance among Directors of Companies. A Proposal for a European Directive and Recent Advances in Europe
}

\author{
By Adoración Pérez Troya*
}

This paper explores recent legal measures adopted in Europe to improve gender balance amongst directors of companies. It focuses on the Proposal for a European Directive on female board members and it refers in brief to different legal measures adopted at national level in many Member States of the European Union, as France, Italy, Spain or Germany. The paper argues that the approval of the proposed Directive must be seen as an urgent issue whereas the equality between women and men is one of the Union's founding values and core aims under the Treaty on European Union. Moreover, a consequence of not taking advantage of the skills of highly qualified women is a waste of talent that Europe can no longer afford. For these reasons the "flexibility" admitted by the compromised text of the proposed Directive (2014) seems excessive and it makes it difficult to understand why women should be less equal in some European member states than in others. ${ }^{1}$

Keywords: Company Board Directors, Gender Balance, European Directive.

\section{Introduction}

Is the glass half empty or half full? If gender balance requires a minimum of $40 \%$ of the under-represented sex on quoted company boards, it would be preferable to see the glass as half full. On average, the $20.2 \%$ of board members of the largest publicly listed companies in the EU are women (See Figure 1). In four member States the rate is over 25\% (France, Latvia, Finland, and Sweden) and in another four they are close to this percentage (Germany, Great Britain, Italy and Denmark). In eighteen countries, including Spain, the rate is below $20 \%$ (See also Figure 1).

\footnotetext{
* Dra. Professor Commercial Law, Law Faculty, Universidad de Alcalá, Spain.

${ }^{1}$ This work has the support of the Spanish "Institute of Women" (Research Project, reference V-397).
} 
Figure 1. Representation of Women on the Boards of Large Listed Companies in the European Union. October 2014

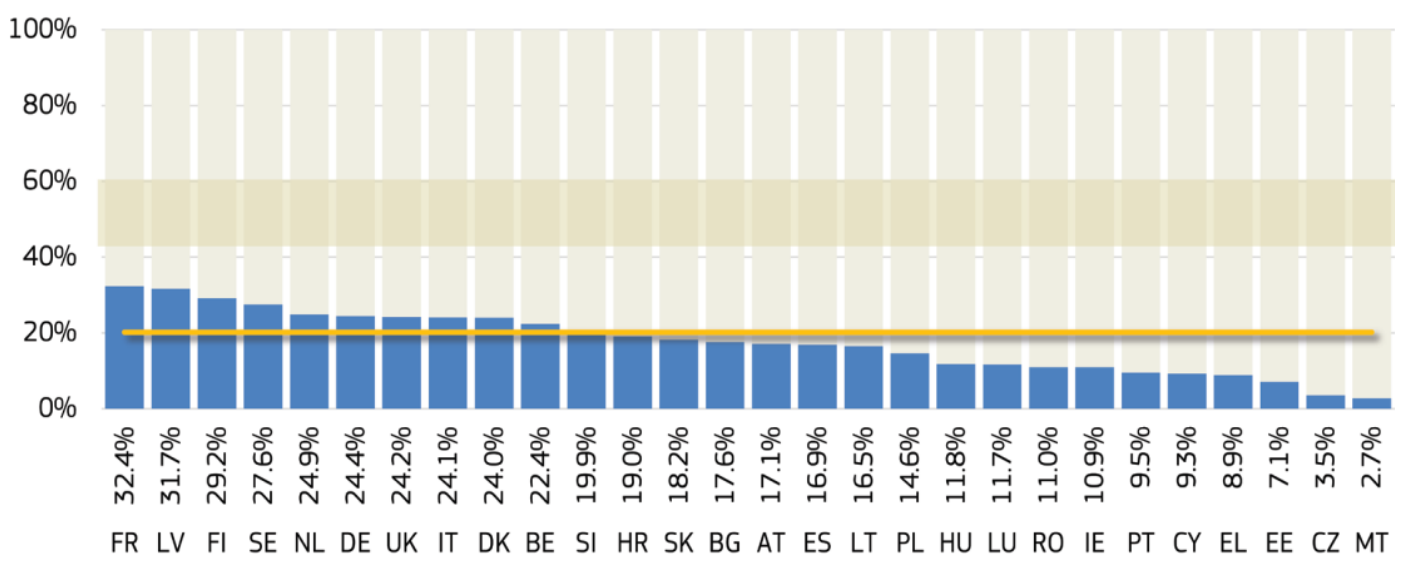

Source: European Commission, Database on women and men in decision-making

The objective of increasing the proportion of women at all levels in a company seems generally shared by stockholders and governments. Studies and reports recognize that a gender diverse board structure reflects a company's customer base more accurately and, as it embraces the economic potential of qualified women who constitute half of the talent pool, is a key for innovation and good corporate governance ${ }^{1}$. However, views still diverge on how the objective can be achieved, namely through regulation following the example of Norway (2003), or through self-regulatory or corporate initiatives, which is the way preferred by companies overall. ${ }^{2}$

\section{The Proposal for a European Directive}

The European Commission, with the support of the European Parliament, decided that taking legislative action at European level was necessary to drive relevant progress on the issue. On 14th November 2012, the Commission approved a proposal for a Directive prescribing by 2020 a minimum objective of $40 \%$ of each sex amongst non-executive directors in companies listed on stock exchanges. ${ }^{3}$ The Proposal, hereinafter referred to as the Reding Proposal (it been particularly championed by the Justice Commissioner Vice President Viviane Reding), is still pending definitive approval. In order to get a broader consensus from the Member States, the Council of the European Union at the end of 2014 proposed some changes in the text, admitting greater flexibility in

\footnotetext{
${ }^{1}$ See, e.g., Catalyst (2007); Adams \& Funk (2011 version); World Bank (2012).

${ }^{2}$ See Teigen (2011).

${ }^{3}$ Proposal for a Directive of the European Parliament and of the Council on improving the gender balance among non-executive directors of companies listed on stock exchanges and related measures (COM (2012) 614). Online: http://eurlex.europa.eu/LexUriServ/LexUriServ. do?uri=COM:2012:0614:FIN:en:PDF.
} 
its application (hereinafter referred as the Compromise text). ${ }^{1}$ However, the Council still did not reach a general approval of the proposal.

\section{The Reding Proposal (2012)}

According to the Proposal, in order to reach the minimum threshold of $40 \%$ of each sex amongst non-executive directors at the deadline fixed (2020, or 2018 in the case of public undertakings), the Member States must enforce companies to put in place mechanisms for transparent appointments, considering clear and gender-neutral criteria in the selection of non-executive directors. Qualification and merit remain the key criteria for being appointed but in case of equal qualifications priority must to be given to the candidate of the under-represented sex. A company below the minimum objective of gender representation is not obliged to appoint a women if it is not able to find an adequate female candidate.

The legal basis of the Proposal is article 157.3 of the Treaty on the Functioning of the European Union (TFEU), which allows the adoption of measures to ensure the application of the principle of equal opportunities and equal treatment of men and women in matters of employment and occupation. The Proposal implies a "positive action" in order to favour the underrepresented sex and has a temporary nature, with an expiry date (may be too optimistically) fixed at 2028. The European Court of Justice has formulated in various judgments to what extend these positive actions are allowed under European Law. ${ }^{2}$ The Proposal is in accordance with them.

On the other hand, trying to preserve the "subsidiarity principle", the Proposal doesn't establish any sanctions on companies that do not achieve the quota on time. It leaves in the hands of the Member States the concrete sanctions that will be applicable to companies, which should continue to apply the procedural rules fixed by the Directive to appoint non-executive directors and they must explain what measures they intend to take in order to reach the minimum required.

The scope of Proposal is limited to large listed companies. SMEs are specifically excluded, even if they are listed. ${ }^{3}$ This exclusion has been criticized by some given that the limited scope of the Directive means that it would embrace about 5.000 companies when there are 21.7 million in total in

\footnotetext{
${ }^{1}$ Council of the European Union, 3357th Council meeting, Employment, Social Policy, Health and Consumer Affairs, Brussels, 11 December 2014. See also, Council of the European Union, Progress Report, Brussels, 11 June 2015.

2“Kalanke”, Case C-450/93, ECR 1995, I-3051; "Marshall”, Case C-409/95, ECR 1997, I6383; "Badeck", Case C-158/97, ECR 2000, I-1902; “Abrahamsson”, Case C-407/98, ECR 2000, I5562.

${ }^{3}$ A SME is defined [Art. 2 (8)] as: "[...] a company which employs less than 250 persons and has an annual turnover not exceeding EUR 50 million or an annual balance sheet total not exceeding EUR 43 million, or, for an SME which is incorporated in a Member State whose currency is not the euro, the equivalent amounts in the currency of that Member State".
} 
Europe. Actually, it would be preferable that listed SMEs dominated by one of the two sexes should be under the scope of the Directive. ${ }^{1}$

Also, the objective of $40 \%$ is limited to positions of non-executive directors/supervisory board members. The Proposal's focus is on non-executive board members, because they are not involved in the day-to-day running of operations. Regarding the executive directors/board members the Proposal only imposes the obligation to set their own targets ("flexi-quota"), leaving companies free in order to fix their own concrete percentages and procedural rules. The difference seeks to preserve equilibrium (principle of proportionality) with other rights also recognized in the Charter of Fundamental Rights of the European Union, namely the freedom to conduct a business (art. 16) and the right to property (art. 17).

The Proposal establishes the possibility for Member States to apply the same objective to both executive and non-executive directors, but in this case a lower target of $33 \%$ would be applicable. This possibility could be attractive for Member States with one-tier board, such Spain. The lower threshold imposed in this case reduces the conflict between the quota and the property rights of the shareholders. However, it is not so clear that a higher threshold could not be considered a proportionate measure as well. As it has been argued, the $40 \%$ target quota for the non-executive directors/supervisory board should not be called into question by this "bonus rate". 2

\section{The Compromise Text (2014): The "Flexibility Clause"}

Seeking a compromise on the Commission's Proposal and taking into account the fact that some Member States were considering passing new laws on the issue, at the end of 2014 the Presidency of the European Council introduced in the text a flexibility clause (art. 4b) and extended the implementation and reporting deadlines (art. 5, 8 and 9). The revised calendar would give Member States and companies more time to prepare their own measures and make progress on the issue, including preparations for applying the flexibility clause.

In practice, these changes imply that the objective to achieve in the different States members a minimum of $40 \%$ women non-executive directors by 2020 could be postpone sine die. The key and controversial point in the Compromise Text is the "flexibility clause", which would allow member states to pursue the aims of the Directive by means of their own choosing, and to suspend the procedural requirements when they have already taken "equally effective" measures or attained progress coming "close" to the objectives set in the Directive. ${ }^{3}$ Article 4b defines some "examples" which would be deemed by law to guarantee "equal effectiveness", leaving open the possibility that the Member States might be entitled to use the flexibility clause in other cases where equal effectiveness or sufficient progress had been demonstrated.

\footnotetext{
${ }^{1}$ Deutscher Juristinnenbund (2014).

${ }^{2}$ Id.

${ }^{3}$ Article 4b: "Suspension of the application of Article 4a".
} 
Moreover, the examples envisaged admit a substantial "discount" from the minimum general threshold of $40 \%{ }^{1}$. It would be enough, beyond 2020 , with $30 \%$ of the total number of all non-executive director positions or $25 \%$ of the total number of all director positions. ${ }^{2}$. In these cases of (doubtful) "equal effectiveness" the procedural requirements to appoint directors ceases to apply, to the detriment to gender equality and also corporate governance.

\section{Advances at National Level}

Since 2010, several member States have changed their legislation aiming to improve gender balance among directors of companies. France, Italy and Belgium legislated for quotas with sanctions. The Netherlands passed a Law establishing a quota without sanctions, and Denmark, Finland, Greece, Austria and Slovenia approved new legislation and regulation for listed companies and or state-owned enterprises. ${ }^{3}$ Spain approved new rules in 2014 for listed companies, but without mandatory quotas and sanctions. This is contrary to what Germany has done in 2015, passing a Law which imposes for the first time in this country a quota with sanctions for the largest German listed companies ${ }^{4}$. In different ways, many countries are acting in order to improve gender balance among directors of companies.

However, the diverse approaches and results in the 28 Member States (See Figure 1) indicate that the need for harmonization persists within the European Union. Two main views exist in this context, dividing the countries into two groups. One with quotas and sanctions and other in line with soft-law and selfregulation. We are going to refer briefly to both groups considering some national examples.

\footnotetext{
${ }^{1}$ Article 4b.1.1.a: "The conditions for the suspension shall be deemed fulfilled where, for example: a) national legislation requires that members of the under-represented sex hold at least $30 \%$ of non-executive director positions or at least $25 \%$ of all director positions no later than 1 January 2020 and effective, proportionate and dissuasive enforcement measures apply in the case of non-compliance with these requirements; b) members of the under-represented sex hold at least $30 \%$ of the total number of all nonexecutive director positions or at least $25 \%$ of the total number of all director positions. c) members of the under-represented sex hold at least $25 \%$ of the total number of all nonexecutive director positions or $20 \%$ of the total number of all director positions and the level of representation has increased by at least 7.5 percentage points in the five years preceding the suspension of the application of Article 4a".

${ }^{2}$ Art. 4b.2: "Member States which have suspended the application of Article 4a pursuant to paragraph 1 may continue this suspension beyond 1 January 2020 only if a) the national legislation complying with the requirements set out in paragraph 1a(a) remains applicable; or b) members of the under-represented sex hold at least $30 \%$ of the total number of all nonexecutive director positions or $25 \%$ of the total number of all director positions by 1 January 2020".

${ }^{3}$ See, e.g., Lambooy (2012).

${ }^{4}$ Gesetz für die gleichberechtigte Teilhabe von Frauen und Männern an Führungspositionen in der Privatwirtschaft und im öffentlichen Dienst, Gesetz vom 24.04.2015 - Bundesgesetzblatt Teil I 2015 Nr. 17 30.04.2015 S. 642. Available at: http://www.bgbl.de/xaver/bgbl/start.xav? startbk=Bundesanzeiger_BGB1\&start=//*\%5b@attr_id=\%2527bgbl115s0642.pdf $\% 2527 \% 5 \mathrm{~d} \#$ _bgbl_\%2F\%2F*\%5B\%40attr_id\%3D\%27bgbl115s0642.pdf\%27\%5D_1440953125112
} 


\section{Member States with Quotas and Sanctions}

In 2011, France introduced a quota mechanism affecting the supervisory and executive boards of listed companies as well big companies which may not be listed with at least 500 employees and an annual net turnover of at least 50 billion euros over the previous three years ${ }^{1}$. Since January $1^{\text {st }}, 2014$ listed companies must nominate at least $20 \%$ of both sexes in supervisory and executive boards. On January 1st, 2017, all companies concerned should meet a share of at least $40 \%$, of both sexes, which will bring around 900 women to the boards of the companies. ${ }^{2}$ Moreover, because of its wide scope, the French quota system provides for two types of sanctions. One relates to the attendance fee granted to the directors ("jetons de presence"), which must not be paid in so far as the company doesn't fulfil the quota. The second, and more important, is that the appointments of new directors to companies not respecting the quota are considered void.

The French quota system has proved to be effective. In 2009 the share of women directors was very low, at around 10\%. By the end of 2011 the average doubled to $20.6 \%$, and it rose again to $24.6 \%$ in 2013, placing France amongst to the few countries where at least one woman was represented in at least one decision-making body of large publicly traded companies. ${ }^{3}$ By October 2014 the percentage has risen to $32.4 \%$, putting France nearer to the $40 \%$ threshold (See Figure 1). These results were also contributed to by initiatives conducted by professional women's associations, such as the one establishing the "List of competent women for Supervisory Boards", making it altogether clear that in France the objective to achieve the $40 \%$ by 2017 is pretty realistic.

Italy also passed a Law in the same year 2011 establishing a quota of onethird of females on boards of listed companies ("quote rosa"). " The same quota has been extended to public undertakings. The system must be followed by the companies progressively, in three consecutives board mandates, requiring that in the first renewal at least $1 / 5$ of the seats would be allocated to women. If any listed company doesn't meet the requirements of the Law, the Market supervisor (Consob) will require the company, who could still have a further 4 months to comply with the legal prescriptions. If the company persists in not complying with the law, a fine of between one hundred thousand and one million euros will be imposed. On the other hand, the directors appointed illegally will then be considered void.

\footnotetext{
${ }^{1}$ Loi no $2011-103$ du 27 janvier 2011 relative à la représentation équilibrée des femmes et des hommes au sein des conseils d'administration et de surveillance et à l'égalité professionnelle. Available at: http://www.legifrance.gouv.fr/affichTexte.do?cidTexte=JORFTEXT000023487 662

${ }^{2}$ Le Nabasque (2011).

${ }^{3}$ Deutscher Juristinnenbund (2014).

${ }^{4}$ Legge 12 luglio 2011, n.120, Modifiche al testo unico delle disposizioni in materia di intermediazione finanziaria, di cui al decreto legislativo 24 febbraio 1998, $n$. 58, concernenti la paritá di acceso agli organi di ammnistrazione e di controllo delle società quotate in mercati regolamentati. (11G0161) (GU n.174 del 28-7-2011). http://www.normattiva.it/urires/N2Ls?urn:nir:stato:legge:2011;120.
} 
In Germany the demand for more diversity in leadership positions and supervisory boards was included in the Corporate Governance Code approved in 2010, following the principle of "comply or explain". However, selfregulation was not fully successful, and in 2013 there were still 19 of the 30 DAX companies with no women on their boards. Overall, the rate of women in supervisory boards and management boards was $14.8 \%$ and only $7.4 \%$ of executive directors were female. ${ }^{1}$ These low rates, the demands for more gender equality by committed sectors, and a final political agreement, led Germany in 2015 to align with the Member States which support mandatory quotas with sanctions. The new system, beginning in 2016, requires that at least $30 \%$ of supervisory board of the listed companies and subject to the codetermination workers' participation requirements, i.e. companies with more than 2000 workers ("Mittbestimung"), shall be allocated to women, establishing the "empty seat" as a sanction. The rest of the listed companies or companies not listed but subject to "Mittbestimung" -around 3.500 companiesmust submit proposals outlining their objectives to increase the share of women in their boards and top management positions.

By means of general debate and the regulatory pressure created since the new Law was announced, the results have become more effective, raising the share of women on the boards of large listed companies to the $24.4 \%$ in October 2014 (See Figure 1). However, it is argued by some that the German quota doesn't go far enough. ${ }^{2}$ It is criticized because only 200 women in a country of 82 million will be immediately affected and the $30 \%$ quota only applies to about 100 companies. However, the example of Germany is significant, because some of the largest European companies are German and German legislation usually has a noticeable influence over the development of the European Company Law and Directives.

\section{Member States with Soft-law and Self-regulation}

United Kingdom has repeatedly expressed its preference for a system without mandatory quotas and sanctions. The "Lord Davies' Review, Women on Boards" in 2011 concluded that "naturally", if nothing is done, the United Kingdom would need at least 70 years more to achieve gender balance on corporate boards. ${ }^{3}$ Due the unpopularity of a system of quotas stated by companies, the Lord Davies' Review recommended to intensify a system of self-regulation in order that at least by 2015 the largest 100 listed companies (FTS 100) will have $25 \%$ of female representation on the boards. Since then, the promotion of self-regulation has indeed been boosted more rigorously by government and general pressure, with good results (See Figure 1). Various civil action groups have been formed for this reason, such as the " $30 \% \mathrm{Club}$ ",

\footnotetext{
${ }^{1}$ Deutscher Juristinnenbund (2014).

2 Lange (2015).

${ }^{3}$ Lord Davies'Review, Women on boards (2011).
} 
which looks to persuade companies to increase the percentage of women on the boards until a share of $30 \%$ is reached. ${ }^{1}$

Spain seemed to be on the avant-garde in this process by approving pretty early in 2007, an Equality Gender Act stating that large companies, not necessary listed on stock exchanges, "will endeavor to include a sufficient number of women on their boards of directors to reach a balance presence of women and men within eight years" ${ }^{2}$. The effectiveness of the provision, which doesn't contemplate sanctions, had a few success however generally has been of limited influence. ${ }^{3}$ In 2003 the share of women on the boards of the companies listed on the IBEX (35 companies) was 3.3\%. In 2007 the share was of $6 \%$ (30 female directors). In the following years from 2008 to 2012, the percentage rose to $12 \%$ and in 2013 to $15.27 \%$ ( 75 female directors) ${ }^{4}$. Public awareness of the issue also contributed alongside the Law to increase the share. $^{5}$

In March 2015 the deadline set by the Spanish legislation to meet a gender balanced representation on the boards of large companies passed. The goal of $40 \%$ was far from being met. To remedy the lack of parity, the Spanish legislation has not been changed to impose a quota system with sanctions, as some proposed ${ }^{6}$. Instead of this, a new Code of Corporate Governance was adopted "recommending" that listed companies aim to have a figure of $30 \%$ of female board members by 2020. Acting in parallel, the Law 31/2014, of 3 December, amended the Corporations Act (Ley de Sociedades de Capital) in several aspects. It introduced the requirement for listed companies to set own "objectives" in order to improve the share of under-represented sex on their boards (art.529 quindicies.3, b). The consequence of the new measures implies a rejection of reaching a gender balance in board composition envisioned by the 2007 Equality Gender Act. This is a step back.

\section{Conclusion}

The proposed Directive is pending definitive approval but it is already having an effect. The share of women on boards in publicly listed companies has increased quickly since the European Commission placed the underrepresentation of women on boards as a priority issue and announced the Proposal. The share of women on boards rose in most countries, and where legislative action was considered at national level or the issue was object of intense public debate the improvements were even better. This was the case in France, Italy, Belgium, Germany, the United Kingdom and Slovenia ${ }^{7}$. The

\footnotetext{
${ }^{1} \mathrm{http}: / / 30$ percentclub.org/

2 Ley Orgánica 3/2007, de 22 de marzo, para la igualdad efectiva de mujeres y hombres. https://www.boe.es/buscar/doc.php?id=BOE-A-2007-6115

${ }^{3}$ Pérez Troya (2013).

${ }^{4}$ See CNMV (2014), Annual Corporate Governance Report of the IBEX 35: Exercise 2013.

${ }^{5}$ See, e.g., Gosálvez (2014); http://www.paridad.eu/

${ }^{6}$ Pérez Troya (2015).

${ }^{7}$ European Commission (2015).
} 
regulatory pressure boosted by the European Commission had significant effect on national legislators, accelerating the approval of different national laws requiring quotas.

However, the "flexibility clause" included in the revised version of the Proposal can dilute this effect. Spain could have been one of the first examples, enacting in 2015 new legislation relying on self-regulation when the actual share of female directors in this country is lower than the mid European average (See Figure 1). The harmonized rules and the objective of a minimum of $40 \%$ non-executive women by 2020 envisaged by the Reding Proposal could be postpone sine die in many Member States. It will become difficult to understand when considering the principles of the internal market, the differences that would exist and be evident between Members States and why women should be less equal in some European Member States than in other.

Notwithstanding the "flexibility clause", the proposed Directive will help to promote fundamental rights related to equality between women and men, and at the same time respect the freedom to conduct a business and the right to property of the shareholders. It will also help corporate governance, in relation to the assumption that companies with a balanced representation of women at their boards have better financial results or other positive economic effects. Under these premises, the approval of the Directive is still an urgent issue, because after all it is unquestionable that not taking advantage of the skills of highly qualified women constitutes a waste of talent and a loss of economic growth potential. Improving the share of women on corporate boards is good but not enough. ${ }^{1}$ We are entitled to demand gender equality and to expect a completely full glass.

\section{References}

$30 \%$ Club. http://30percentclub.org/

Adams, R. \& Funk, P. (2011 version). "Beyond the Glass Ceiling: Does Gender matter?" SSRN eLibrary. Available at: http://papers.ssrn.com/sol3/papers.cfm? abstract_id=1475152 (last visited June 21, 2015).

Catalyst (2007). The Bottom Line: Corporate Performance and Women's Representation on Boards. Available at: http://www.catalyst.org/system/files/ The Bottom Line Corporate Performance and Womens Representation on B oards.pdf (last visited June 12, 2015).

Comisión Nacional del Mercado de Valores (2014). Annual Corporate Governance Report of the IBEX 35: Exercise 2013. Available at: http://www.cnmv.es/DocPor tal/Publicaciones/Informes/IAGC IBEX35 2013.pdf (last visited June 12, 2015).

Council of the European Union (2015). Interinstitutional File: 2012/0299 (COD). Report from Presidency to Permanent Representatives Committee/Council, Proposal for a Directive of the European Parliament and of the Council on improving the gender balance among directors of companies listed on stock exchanges and related measures. Progress Report, Brussels, 11 June 2015.

\footnotetext{
${ }^{1}$ See European Women Shareholders Demand Gender Equality: http://www.ewsdge.eu/
} 
Available at: http://data.consilium.europa.eu/doc/document/ST-9020-2015-REV1/en/pdf (last visited July 10, 2015).

Deutscher Juristinnenbund (2014). Advisory Opinion on the Proposal for a Directive of the European Parliament and of the Council on improving the gender balance among non-executive directors of companies listed on stock exchanges and related measures (COM (2012) 614), Berlin, May 19th, 2014. http://www.djb. de/extras/suche/

European Commission (2015). Gender balance on corporate boards. Europe is cracking the glass ceiling, http://ec.europa.eu/justice/gender-equality/files/wome nonboards/wob-factsheet_2015-01_en.pdf

European Women Shareholders Demand Gender Equality. http://www.ewsdge.eu/ (last visited August 28, 2015).

Gosálvez, P. (2014). "Más mujeres señores consejeros", El País, 8th June, 2014, available at: http://sociedad.elpais.com/sociedad/2014/06/04/actualidad/1401892 415 693997.html (last visited June 21, 2015).

Lambooy, T. (2012). "30 percent Women on Boards: New Law in the Netherlands, European Company Law, vol. 9, No. 2. Available at: http://papers.ssrn.com/sol3/ papers.cfm?abstract $\mathrm{id}=2083449$ (last visited June 10, 2015).

Lange, K. (2015). "Lichtstreif am Horizont? Über das Gesetz zur gleichberechtigten Teilhabe für Frauen und Männer in der Privatwirtschaft", DJBZ Zeitschrift des Deutschen Juristinnenbundes, 2/2015.

Le Nabasque, H. (2011). "Loi Cope-Zimmerman no 2011-103 du 27 janvier 2011 relative a la representation équilibrée des femmes et des hommes au sein des conseils d'administration et de surveillance (de certaines sociétés) et à l'égalité professionnelle", Revue des Sociétés, ${ }^{\circ}$ 7-8.

Lord Davies of Abersoch. (2011), Lord Davies'Review, Women on boards. Available at: https://www.gov.uk/government/uploads/system/uploads/attachment_data/file 131480/11-745-women-on-boards.pdf (last visited June 12, 2015).

Paridad en acción. http://www.paridad.eu/

Pérez Troya, A. (2013). "La incorporación de la perspectiva de género al Derecho Mercantil, Revista de Derecho Mercantil, n 288. http://www.paridad.eu/docs/ APT-genero.pdf.

Pérez Troya, A. (2015). “¿Será 2015 el año de la cuota de género en los consejos?”, el diario.es, 21.2.2015, http://www.eldiario.es/agendapublica/impacto_social/anocuota-genero-consejos-administracion_0_359064472.html.

Teigen, M. (2011). "Gender Quotas in Corporate Boards. The Norwegian Experience". Presentation. Institutt for samfunnsforskning. Available at: http:// www.vi.is/files/2011.05.13-Virkjum-Mari_1266626698.pdf (last visited June 12, 2015).

World Bank (2012). World Bank's annual World Development Report. Gender Equality and Development. Available at: http://wdronline.worldbank.org/ (last visited June 21, 2015). 